\title{
Pengaruh sokongan penyelia dalam perhubungan antara tekanan kerja dan konflik kerja-keluarga
}

\author{
Nur Izzaty Mohamad ${ }^{1}$, Azman Ismail ${ }^{1,2}$, Azmawaty Mohamad Nor ${ }^{3}$ \\ ${ }^{1}$ Institut Islam Hadhari, Universiti Kebangsaan Malaysia \\ ${ }^{2}$ Fakulti Ekonomi dan Pengurusan, Universiti Kebangsaan Malaysia, \\ ${ }^{3}$ Fakulti Pendidikan, Universiti Malaya
}

Correspondence: Nur Izzaty Mohamad (email: nurizzaty_mohamad@yahoo.com)

Received: 01 March 2020; Accepted: 15 May 2020; Published: 30 May 2020

\begin{abstract}
Abstrak
Tekanan kerja dapat mempengaruhi kesejahteraan dan prestasi organisasi. Kajian terbaharu mendedahkan bahawa tahap tekanan kerja mempunyai tiga elemen yang sangat penting, iaitu kesamaran tanggungjawab, pertelingkahan tanggungjawab dan beban tanggungjawab. Tahap tekanan yang tinggi tidak meningkatkan konflik kerja-keluarga apabila kesanggupan penyelia menghulurkan sokongan kepada pekerja dalam organisasi. Sungguhpun perhubungan ini dikaji secara meluas, namun peranan sokongan penyelia sebagai pemboleh ubah penyederhanaan yang efektif kurang dibincangkan secara terperinci dalam literatur penyelidikan tingkah laku organisasi. Kajian ini dilaksanakan untuk menilai perhubungan antara tekanan kerja, sokongan penyelia dan konflik kerja-keluarga. Borang soal selidik tadbir sendiri telah digunakan untuk mengumpulkan data daripada staf yang berkhidmat di berbagai bahagian dalam sebuah agensi pusat kerajaan persekutuan Malaysia. Keputusan analisis model SmartPLS menunjukkan bahawa tahap tekanan kerja (tahap kesamaran tanggungjawab, pertelingkahan tanggungjawab dan beban tanggungjawab) yang tinggi tidak berupaya meningkatkan konflik kerja-keluarga apabila penyelia sanggup menghulurkan sokongan yang berkesan dalam melaksanakan operasi kerja harian. Oleh itu, dapatan kajian ini boleh digunakan sebagai perakuan-perakuan penting bagi membantu pihak pengurusan dalam memahami konsep sokongan penyelia yang bersifat multidimensi dan merangka program sokongan pekerja bagi mencapai dan mengekalkan misi dan wawasan organisasi dalam zaman globalisasi dan ekonomi yang sukar diramalkan.
\end{abstract}

Kata kunci: konflik kerja-keluarga, sokongan penyelia, SmartPLS, tekanan kerja 


\title{
Influence of supervisor support in the relationship between work stress and family-work conflicts
}

\begin{abstract}
Work stress may affect organizational performance and well-being. Recent studies disclosed that work stress consists three important elements, namely responsibility ambiguity, responsibility conflict and workload responsibility. High level of work stress does not enhance work-family conflict with supervisors' willingness to provide effective support in organizations. Although this relationship were widely researched, the role of supervisor support as an essential moderating variable is not thoroughly discussed in the organizational behavior research literature. This research was carried out to evaluate the relationship between work stress, supervisor support and work-family conflict. Self-report questionnaires were applied to gather data from employees at a central agency of Malaysian federal government. The results of SmartPLS displayed that high level of work stress (responsibility ambiguity, responsibility conflict and workload responsibility) had not enhanced work-family conflict with supervisors' willingness to provide effective support in executing daily job operations. Therefore, this result can be used as important recommendations by management to understand the multidimensional concept of supervisor support and formulate employee assistant programs in order to maintain and support their organizations' vision and missions in times of globalization and unpredictable economic.
\end{abstract}

Keywords: work-family conflict, supervisor support, SmartPLS, work stress

\section{Pengenalan}

Perkembangan global dalam abad ke-21 seperti ekonomi berasaskan pengetahuan, hubungan diplomatik antara negara, perjanjian perdagangan antarabangsa dan revolusi industri 4.0 telah mendorong organisasi swasta dan awam mengubah paradigma kepimpinan daripada pengurusan berasaskan kerja rutin kepada gabungan pengurusan maklumat dan penggunaan teknologi tinggi bagi menjayakan falsafah dan objektif organisasi (Schwab, 2017; Ślusarczyk, 2018). Pentadbir mengaplikasi kreativiti dalam cara melakukan kerja harian berasaskan kertas dan pensil kepada cara kerja berorientasikan teknologi digital (Schwab, 2017; Ślusarczyk, 2018). Pekerja didorong untuk mempelajari dan menguasai kompetensi serta menyesuaikan diri dengan persekitaran kerja baharu. Keadaan ini menghasilkan tekanan fizikal dan mental dalam kalangan pekerja (Vickovic \& Morrow, 2019; Erny Yusnida, Haslinda \& Zatul Himmah 2017; Smith, et al., 2020).

Dalam konteks psikologi organisasi Barat, tekanan kerja berasal daripada perkataan Latin iaitu "stringere" yang sering dikaitkan dengan penderitaan fizikal dan psikologi manusia (Birhanu et al., 2018). Ia ditafsirkan secara umum sebagai beban kehidupan yang ditanggung oleh pekerja yang menghasilkan kesan yang tidak bersifat spesifik ke atas diri mereka (Nur Izzaty et al., 2015; Rabenu, Tziner \& Sharoni, 2017; Vickovic \& Morrow, 2019; Smith, et al., 2020). Sebagai contoh, pekerja sering menerima isyarat gangguan daripada tugas harian seperti peningkatan desakan kerja dan sumber tenaga yang terhad. Pekerja yang berupaya mengendalikan gangguan tersebut secara teratur mengalami tekanan kerja positif, seperti bermotivasi melaksanakan kerja dan memperbaiki prestasi kerja harian. Sebaliknya, pekerja yang tidak dapat mengendalikan gangguan maka akan mengalami tekanan kerja negatif, seperti kebimbangan, gangguan fizikal dan mental serta prestasi kerja yang merosot 
(Rabenu, Tziner \& Sharoni, 2017; Erny Yusnida, Haslinda \& Zatul Himmah 2017; Nur Izzaty et al., 2015; Vickovic \& Morrow, 2019)

Penelitian kajian lepas berkaitan transformasi organisasi membuktikan bahawa sistem kerja yang dirancang rapi tidak berupaya untuk mencapai matlamat sekiranya pekerja tidak dapat mengendalikan tekanan kerja secara teratur (Hirschi, 2018; Lee et al., 2018). Kajian oleh Nabavi dan Shahryari (2012), Nur Izzaty et al. (2015) dan Tharmalingam dan Bhatti (2014), mengatakan bahawa tekanan kerja mempunyai tiga ciri yang kritikal: kesamaran tanggungjawab, pertelingkahan tanggungjawab dan beban tanggungjawab. Kesamaran tanggungjawab ditakrifkan sebagai arahan tugas oleh penyelia kepada pekerja adalah tidak jelas (seperti objektif kerja, senarai tugas dan tatacara kerja dan sukar memilih cara bertindak yang sesuai mengikut situasi kerja). Akibatnya, pekerja berasa tidak pasti dalam mengurus dan melaksanakan operasi kerja harian (Rabenu, Tziner \& Sharoni, 2017; Tharmalingam \& Bhatti, 2014).

Manakala, pertelingkahan tanggungjawab merupakan ketidakupayaan pekerja untuk melaksanakan tuntutan kerja dan menyebabkan pekerja tersebut tidak berasa gembira dalam pekerjaannya (Nur Izzaty et al., 2015; Tharmalingam \& Bhatti, 2014; Vickovic \& Morrow, 2019). Beban tanggungjawab pula mempunyai dua ciri utama: bebanan tugas kuantitatif dan bebanan tugas kualitatif. Beban kerja kuantitatif ditakrifkan sebagai pekerja melaksanakan tugas yang sangat banyak sedangkan tempoh untuk menyelesaikan tugasan tersebut adalah tidak mencukupi. Sebaliknya, beban kerja kualitatif merupakan pelaksanaan beban tugas yang rumit dan mencabar yang dihadapi pekerja. Sekiranya beban tanggungjawab ini tidak dilaksanakan oleh pekerja secara teratur, pekerja boleh mengalami tekanan kerja yang negatif (Adnan, Suad \& Asad, 2016; Sunanda, 2018).

Kajian oleh Jun Ju et al. (2017), Sunanda (2018) dan Wang, Shelly \& Lin (2018) membuktikan tekanan kerja adalah gejala yang sangat imperatif dalam organisasi. Kebanyakan kajian mengetengahkan bahawa ketidakupayaan pekerja mengendalikan tekanan kerja dapat meningkatkan konflik kerja-keluarga (Adnan, Suad \& Asad, 2016; Jun Ju et al., 2017; Nur Izzaty et al., 2015). Daripada perspektif gelagat organisasi, konflik-kerja keluarga berkait rapat dengan kesukaran pekerja mengimbangi urusan kerja dan keluarga termasuk ketidakupayaan mengatur peranan kerja dengan keluarga secara adil, pembahagian masa bekerja dan keluarga, merancang perjalanan tanggungjawab kerja dan keluarga secara teratur. Pelanjutan keadaan ini mengakibatkan kebahagiaan keluarga terganggu (Tavassoli \& Sune, 2018; Asad, 2018; Vickovic \& Morrow, 2019).

Dewasa ini, tekanan kerja telah dilihat sebagai gejala yang kritikal dalam organisasi yang berdaya saing. Dapatan kajian tentang kesejahteraan organisasi mengetengahkan ketidakupayaan menghadapi tekanan kerja yang tinggi, meningkatkan konflik kerja-keluarga sekiranya tiada sokongan penyelia (Curran \& Prottas, 2017; Jun Ju et al., 2017; Vickovic \& Morrow, 2019). Sokongan penyelia merujuk kepada kesanggupan penyelia menghulurkan bantuan moral dan instrumental bagi meningkatkan kesejahteraan pekerja dalam organisasi (Tharmalingam \& Bhatti, 2014; Tavassoli \& Sune, 2018). Dalam perspektif organisasi, sokongan moral ialah kesediaan penyelia memberi pengiktirafan terhadap kejayaan, menghargai tugasan, memotivasikan dan prihatin terhadap masalah pekerja bawahan. Manakala, sokongan instrumental merupakan bantuan berbentuk material termasuk penyediaan peralatan kerja yang terkini, mengagihkan belanjawan kewangan secara adil serta menyediakan tabung kecemasan untuk kebajikan pekerja dalam pelaksanaan tugas rasmi ( $\mathrm{Yu}$ Fei et al., 2012; Tavassoli \& Sune, 2018).

Kajian literatur tekanan organisasi tidak banyak membincangkan saiz kesan dan sifat sokongan penyelia sebagai pemboleh ubah penyederhanaan (Tavassoli \& Sune, 2018; Tharmalingam \& Bhatti, 2014). Ianya mungkin dipengaruhi oleh faktor: Pertama, kebanyakan kajian lepas menggunakan pendekatan deskriptif yang menghuraikan takrif 
konseptual, jenis dan kepentingan sokongan penyelia dalam organisasi swasta dan awam (Nabavi \& Shahryari, 2012; Rabenu, Tziner \& Sharoni, 2017). Kedua, kajian-kajian lepas membincangkan pendekatan model kesan langsung yang menilai perhubungan antara dua jenis pemboleh ubah iaitu: 1) persepsi pekerja terhadap tekanan kerja; 2) perhubungan antara tekanan kerja dan sokongan penyelia; 3) perhubungan antara tekanan kerja dan konflik kerjakeluarga; dan 4) perhubungan antara sokongan penyelia dan konflik kerja-keluarga (Nurul Habibatunn, Zirwatul Aida \& Mazida, 2018; Tharmalingan, 2014). Perhubungan antara pemboleh ubah tersebut hanya dinilai menggunakan analisis statistik tingkah laku mudah, seperti statistik deskriptif dan bivariat yang hanya berupaya menerangkan sifat dan darjah keteguhan korelasi (Fu \& Shaffer, 2001; Asad, 2018). Oleh itu, ia tidak berupaya untuk mengukur saiz kesan dan sifat sokongan penyelia sebagai pemboleh ubah penyederhanaan (Rabenu, Tziner \& Sharoni, 2017; Sunada, 2018; Wang et al., 2018). Natijahnya, pendekatan tersebut hanya memadai digunakan sebagai panduan bagi memahami konsep sokongan penyelia yang bersifat multidimensi dalam merangka program sokongan pekerja bagi meningkat dan mengekalkan prestasi serta daya saing organisasi (Meguellati et al., 2017; Straub et al., 2018). Justeru, pengkaji ingin menilai peranan sokongan penyelia sebagai pemboleh ubah penyederhanaan antara tekanan kerja dan konflik kerja-keluarga.

\section{Kajian literatur}

Perhubungan antara tekanan kerja dan konflik kerja-keluarga

Peranan tekanan kerja dalam mempengaruhi konflik kerja-keluarga adalah konsisten dengan maksud Teori Sempadan Kerja-Keluarga (Clark, 2002). Ianya mengutarakan bahawa darjah kesamaran tanggungjawab, pertelingkahan tanggungjawab dan beban tanggungjawab yang tinggi adalah faktor yang berupaya meningkatkan gangguan kerja terhadap kesejahteraan keluarga. Kajian-kajian yang menyokong teori ini membincangkan penilaian tekanan kerja menggunakan sampel organisasi yang berlainan seperti persepsi 368 kakitangan wanita yang sudah berkahwin di Pejabat Ahwaz, Iran (Nabavi \& Shahryari, 2012), persepsi 200 staf akademik di sebuah universiti awam di Malaysia (Azman et al., 2014), persepsi 250 pekerja wanita di beberapa universiti awam di Nigeria (Ogbogu, 2013) dan persepsi 260 pekerja dari lapan syarikat swasta di Terengganu (Nurul Habibatunn et al., 2018). Dapatan kaji selidik tersebut melaporkan ketidakupayaan pekerja mengendalikan tahap kesamaran tanggungjawab, pertelingkahan tanggungjawab dan beban tanggungjawab yang tinggi dalam melaksanakan tugas dan tanggungjawab harian meningkatkan gangguan kerja dan keharmonian keluarga. Hipotesis yang diuji adalah:

H1: Kesamaran tanggungjawab mempunyai hubungan yang positif dengan konflik kerja keluarga

H2: Pertelingkahan tanggungjawab mempunyai hubungan yang positif dengan konflik kerjakeluarga

H3: Beban tanggungjawab mempunyai hubungan yang positif dengan konflik kerja-keluarga

\section{Perhubungan antara Tekanan Kerja, Sokongan Penyelia dan Konflik Kerja-Keluarga}

Peranan sokongan penyelia sebagai pemboleh ubah penyederhanaan selari dengan idea utama dalam Teori Pertukaran Pemimpin-Pengikut (Dansereau, Graen \& Hage, 1975). Ia membincangkan kualiti perhubungan yang tinggi antara penyelia dan pengikut membantu 
mewujudkan keharmonian antara urusan kerja dan peribadi pekerja. Aplikasi teori ini dalam model tekanan kerja menunjukkan bahawa kualiti perhubungan yang tinggi antara penyelia dan pekerja diterjemahkan sebagai sokongan penyelia. Saranan teori ini mendapat sokongan yang padu daripada kajian lepas yang berkaitan sokongan organisasi (Nur Izzaty et al., 2015; Asad, 2018).

Kajian baharu berdasarkan model kesan tidak langsung menggunakan sampel kajian yang berlainan, seperti persepsi 267 kakitangan akademik dan bukan akademik di Universiti Hong Kong (Fu \& Shaffer, 2001), 200 kakitangan pentadbiran di Universiti Utara Malaysia (Tharmalingan, 2014) dan 307 pekerja dalam pelbagai organisasi sektor awam di Pakistan (Asad, 2018). Dapatan kaji selidik tersebut mendedahkan tahap kesamaran tanggungjawab, pertelingkahan tanggungjawab dan beban tanggungjawab tidak berupaya meningkatkan konflik kerja-keluarga apabila penyelia menghulurkan sokongan emosi dan instrumental dalam organisasi. Hipotesis yang diuji adalah:

H4: Kesan kesamaran tanggungjawab terhadap konflik kerja-keluarga disederhanakan oleh sokongan penyelia

Hs: Kesan pertelingkahan tanggungjawab terhadap konflik kerja-keluarga disederhanakan oleh sokongan penyelia

H6: Kesan beban tanggungjawab terhadap konflik kerja-keluarga disederhanakan oleh sokongan penyelia

\section{Kerangka Konseptual dan Hipotesis Kajian}

Kajian literatur digunakan sebagai panduan untuk membina kerangka konseptual. Rajah 1 memaparkan kesan tekanan kerja ke atas konflik-kerja keluarga disederhanakan oleh sokongan penyelia.

Pemboleh Ubah Tidak Bersandar

Pemboleh Ubah Bersandar

(Tekanan Kerja)

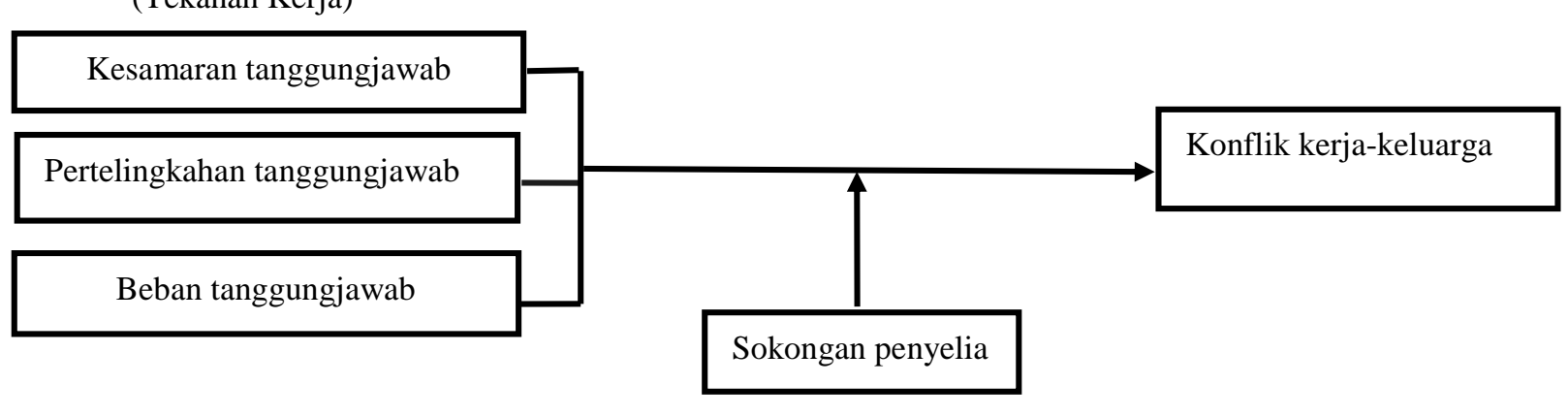

Pemboleh Ubah Penyederhanaan

Rajah 1. Kerangka kajian

\section{Metodologi}

\section{Reka bentuk kajian}

Kajian ini dilaksanakan di sebuah agensi pusat kerajaan Persekutuan Malaysia. Peringkat dan kategori pekerjaan telah direka bentuk mengikut perkembangan teknologi digital termaju. Pelaksanaan kerja berasaskan teknologi digital mengubah kestabilan gaya bekerja kepada lebih anjal dan mencabar. Penggunaan infrastruktur teknologi komunikasi yang canggih, 
seperti internet dan telefon pintar telah mendorong pekerja untuk respon kepada pelanggan 24 jam dan meningkatkan perkhidmatan kerja yang lebih panjang. Campur tangan urusan kerja yang berterusan telah mengganggu hal ehwal kehidupan peribadi dan keluarga. Laporan daripada para pekerja dan wakil-wakil persatuan kakitangan dalam perkhidmatan awam Malaysia menunjukkan pihak pengurusan berjaya mengendalikan kesan negatif tekanan kerja melalui program sokongan pekerja. Penyelia telah diberikan latihan secara modular oleh Institut Tadbiran Awam Negara (INTAN) dan diberikan autonomi oleh pihak pengurusan untuk mengamalkan gaya kepimpinan sokongan, seperti menghulurkan sokongan emosi (galakan, keprihatinan, bersifat terbuka) dan sokongan instrumental (mewujudkan persekitaran tempat kerja yang teratur, menyusun atur kelengkapan kerja) dalam membantu pekerja melaksanakan operasi kerja harian. Amalan sokongan merupakan bantuan yang amat berguna bagi pekerja memperbaiki kesilapan menjalankan tugas harian, meningkatkan kecekapan kerja harian dan membantu merancang pembangunan kerjaya dalam organisasi. Walaupun sokongan penyelia adalah imperatif, namun keupayaannya mengurangkan tekanan kerja dan konflik kerja-keluarga tidak dikaji secara mendalam dalam organisasi tersebut. Ini mendorong pengkaji untuk menilai peranan sokongan penyelia sebagai pemboleh ubah penyederhanaan yang penting dalam perhubungan di antara tekanan kerja dan konflik kerjakeluarga.

Kaji selidik telah digunakan sebagai strategi penyelidikan yang membenarkan pengkaji menggunakan reka bentuk keratan rentas bagi menggumpulkan borang-borang selidik sebagai prosedur utama dalam penggumpulan data. Ianya memudahkan pengkaji mengumpulkan data kajian yang tepat, kurang bias dan berkualiti (Creswell, 2015; Sekaran \& Bougie, 2016). Soal selidik kajian dirangka berdasarkan kajian literatur yang berkaitan tekanan kerja. Seterusnya, teknik terjemahan berbalik digunapakai untuk menterjemah borang soal selidik ke dalam bahasa Melayu dan Inggeris bagi meningkatkan ketepatan dan kebolehpercayaan instrumen kajian (Sekaran \& Bougie, 2016).

\section{Alat pengukuran}

Borang soal selidik kajian mempunyai 3 bahagian. Pertama, kesamaran tanggungjawab (KSMTB) dinilai menggunakan 14 item, pertelingkahan tanggungjawab (PTGHB) dinilai menggunakan 9 item dan beban tanggungjawab (BBNTB) dinilai menggunakan 3 item yang diadaptasikan daripada kajian literatur tekanan kerja (Ray \& Miller, 1994; Rizzo, House \& Lirtzman, 1970). KSMTB diukur menggunakan 3 elemen, iaitu objektif tugas, senarai tugas dan arahan tugas. PTGHB diukur menggunakan 3 elemen, iaitu arahan kerja, peraturan kerja dan persefahaman dengan penyelia. BBNTB diukur menggunakan 3 elemen, iaitu masa, tenaga dan tugas. Kedua, sokongan penyelia (SKGPB) dinilai menggunakan 10 item yang diadaptasi daripada kajian literatur sokongan organisasi (Azman et al., 2013; Ray \& Miller, 1994). SKGPB diukur menggunakan 3 elemen, iaitu motivasi, layanan dan bimbingan. Ketiga, konflik kerja-keluarga (KKKLB) dinilai menggunakan item yang diadaptasi daripada kajian literatur keseimbangan kerja-kehidupan (Netemeyer, Boles \& Mcmurrian, 1996). KKKLB diukur menggunakan 3 elemen, iaitu tanggungjawab, komitmen dan hubungan. Kesemua item dalam soal selidik ini dinilai menggunakan skala jawapan 7 pilihan, iaitu daripada "sangat tidak setuju/sangat tidak puas hati" (1) hingga "sangat setuju/sangat puas hati” (7). Ciri-ciri demografi responden digunakan sebagai pemboleh ubah kawalan kerana peranannya sebagai pemboleh ubah peramal tidak mendapat sokongan daripada teori-teori dan kajian-kajian empirikal yang berkaitan dengan tujuan kajian, kerangka konseptual dan hipotesis kajian (Nur Izzaty et al., 2015; Azman et al., 2014). Oleh itu, kaji selidik telah digunakan untuk menilai isu kajian berdasarkan persepsi pekerja secara umum. 


\section{Sampel kajian}

Unit analisis kajian ini ialah pekerja yang bertugas dalam organisasi kajian. Teknik pensampelan bertujuan digunapakai untuk mengedarkan 300 borang soal selidik kepada pekerja yang berbeza peringkat dan pengkelasan kerja serta berkhidmat di pelbagai jabatan/bahagian dalam organisasi kajian. Ia diaplikasi kerana pengurusan organisasi tidak dapat menyediakan senarai pekerja berdaftar yang lengkap atas faktor kerahsiaan mengakibatkan teknik rawak tidak dapat diaplikasi. Sejumlah 190 (63\%) soal selidik yang dijawab dengan lengkap telah dikembalikan kepada pengkaji. Responden kajian menjawab dengan persetujuan, tanpa paksaan dan kerahsiaan. Seterusnya, bagi menentukan tahap maklum balas bias dalam sampel kajian ini, ujian Harman's Single Factor telah dilaksana berdasarkan perakuan oleh Eichhorn (2014) dan Padsakoff et al. (2003). Keputusan ujian ini menunjukkan bahawa peratusan varian adalah $48 \%$ iaitu kurang daripada nilai $50 \%$ (Eichhorn, 2014; Padsakoff et al., 2003). Ini bererti maklum balas bias bukanlah masalah kritikal dalam data borang soal selidik kajian ini.

\section{Analisis data}

Perisian SmartPLS digunakan untuk menganalisis data borang soal selidik berdasarkan panduan disyorkan oleh Hair et al. (2017). Pertama, analisis model pengukuran dilaksanakan untuk menentukan kesahan dan kebolehpercayaan instrumen kajian (Gefen \& Straub, 2005; Henseler, Ringle \& Sinkovics 2009; Ringle, Wende \& Will, 2005). Kedua, analisis model struktural dilaksanakan untuk menguji model kesan langsung dan model pemboleh ubah penyederhanaan. Hipotesis yang signifikan dapat dikenalpasti apabila nilai-t adalah signifikan $(\mathrm{t}>1.65)$. Ketiga, nilai $\mathrm{R}^{2}$ digunakan untuk menilai tahap kekuatan model kajian berdasarkan tiga kriteria utama iaitu 0.26 teguh, 0.13 sederhana dan 0.02 lemah (Cohen, 1992). Keempat, nilai estimated root mean square residual (SRMR) yang kurang daripada 0.08 atau $10.0(\mathrm{Hu}$ \& Bentler, 1999), menunjukkan bahawa model kajian yang digunakan adalah sesuai. Kelima, nilai $\mathrm{f}^{2}$ turut digunakan bagi menilai kesan saiz berdasarkan tiga kriteria penting iaitu 0.35 teguh, 0.15 sederhana dan 0.02 kecil. Seterusnya, nilai blindfolding $\left(\mathrm{Q}^{2}\right)$ diukur berdasarkan kriteria nilai yang lebih besar daripada sifar, bermaksud konstruk mencapai tahap ketepatan ramalan yang disyorkan oleh Hair et al. (2017).

\section{Dapatan kajian}

Kebanyakan responden kajian berumur 28 hingga 33 tahun (42.6\%), Melayu (95.8\%), Islam (95.8\%), perempuan (58.4\%), pemegang Diploma (35.8\%), kumpulan perkhidmatan pelaksana (67.9\%), bekerja harian 8 jam hingga 10 jam $(89.5 \%)$, bergaji kasar bulanan RM1000 dan RM2499 (47.4\%) serta telah berkhidmat 6 hingga 10 tahun (51.6\%).

\section{Analisis kesahan dan kebolehpercayaan instrumen}

Jadual 1 memaparkan kesahan konvergen yang diukur berdasarkan nilai pemberat dan nilai ekstrak varian purata (AVE). Korelasi antara item dengan konstruk kajian mempunyai nilai pemberat lebih besar daripada 0.70 dan setiap konstruk mempunyai nilai AVE lebih besar daripada 0.50 (Hair et al., 2017), bermaksud konstruk telah memenuhi tahap piawaian kesahan konvergen. 
Jadual 1. Dapatan ujian kesahan konvergen dan AVE

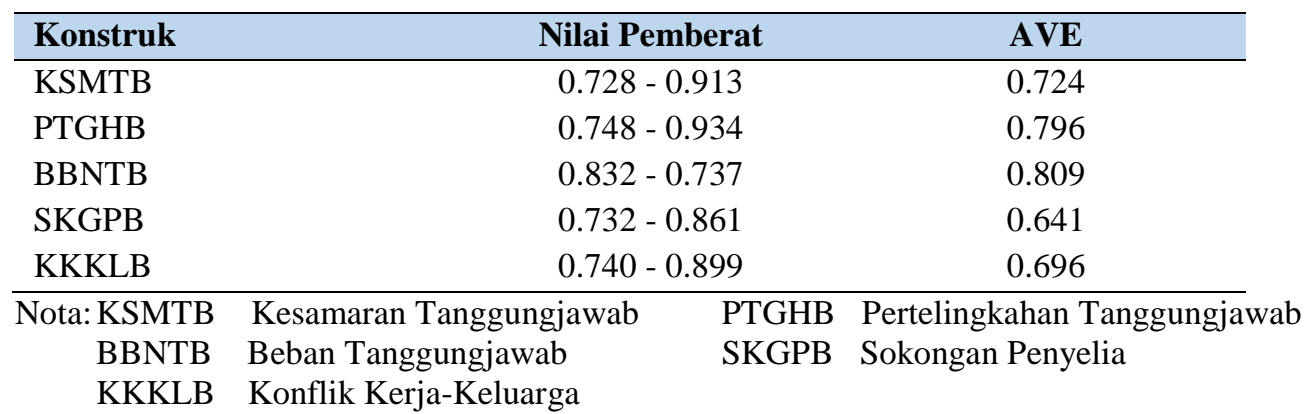

Jadual 2 menunjukkan kesahan diskriminan dan kebolehpercayaan komposit. Nilai heterotrait-monotrait ratio (HTMT) bagi setiap konstruk kurang daripada 0.85 dan nilai selang keyakinan dalam kurungan bagi setiap konstruk kurang daripada nilai 1, yang bermakna konstruk kajian ini telah mencapai kesahan diskriminan yang telah ditetapkan. Seterusnya, nilai kebolehpercayaan komposit bagi setiap konstruk melebihi 0.80 (Hair et. al., 2017), yang bererti konstruk kajian ini mencapai tahap kebolehpercayaan yang tinggi.

Jadual 2. Dapatan ujian kesahan diskriminan HTMT, selang keyakinan HTMT dan kebolehpercayaan komposit

\begin{tabular}{lccccc}
\hline Konstruk & KSMTB & PTGHB & BBNTB & SKGPB & $\begin{array}{c}\text { Kebolehpercayaan } \\
\text { Komposit }\end{array}$ \\
\hline KSMTB & & & & 0.973 \\
PTGHB & & & & 0.972 \\
BBNTB & 0.202 & 0.454 & 0.282 & 0.876 \\
SKGPB & $(0.027,0.375)$ & $(0.275,0.633)$ & $(0.162,0.390)$ & 0.981 \\
KKKLB & & & & 0.723 & 0.958 \\
\hline
\end{tabular}

Nota: Dalam kurungan ialah nilai selang keyakinan pada $2.5 \%$ dan $97.5 \%$

\section{Analisis konstruk}

Jadual 3 memaparkan statististik asas dan analisis korelasi Pearson. Nilai min bagi setiap konstruk kajian berada di antara 4.054 dan 5.831, yang menunjukkan bahawa KSMTB, PTGHB, BBNTB, SKGPB dan KKKLB berada di antara tahap tinggi (4) dan sangat tinggi (7). Manakala korelasi antara a) KSMTB, PTGHB dan BBNTB dengan SKGPB dan b) SKGPB dengan KKKLB mempunyai nilai faktor inflasi varian kurang daripada 5.0 (Hair et al., 2017), mengesahkan semua pemboleh ubah kajian bebas daripada masalah kolineariti.

Jadual 3. Keputusan statistik asas dan analisis Faktor Inflasi Varian

\begin{tabular}{llcc}
\hline Konstruk & Min & Sisihan Piawai & Faktor Inflasi Varian \\
\hline KSMTB & 5.831 & 0.665 & 3.196 \\
PTGHB & 4.976 & 0.654 & 3.426 \\
BBNTB & 4.054 & 0.838 & 1.349 \\
SKGPB & 5.640 & 0.647 & 2.352 \\
\hline
\end{tabular}




\section{Dapatan pengujian $\mathrm{H}_{1}, \mathrm{H}_{2}$ dan $\mathrm{H}_{3}$}

Jadual 4 memaparkan kadar perubahan dalam pemboleh ubah bersandar iaitu KSMTB telah menyumbang sebanyak 0.41 perubahan dalam KKKLB. Nilai sumbangan ini lebih lebih besar daripada 0.26 (Cohen, 1992), bermaksud model kajian ini mempunyai kesan yang besar. Seterusnya, PTGHB telah menyumbang sebanyak 0.51 perubahan dalam KKKLB. Nilai sumbangan ini lebih besar daripada 0.26 (Cohen, 1992), bermakna model kajian ini mempunyai kesan yang besar (Cohen, 1992). Manakala, BBNTB telah menyumbang sebanyak 0.44 perubahan dalam KKKLB. Nilai sumbangan ini adalah lebih lebih besar daripada 0.26 (Cohen, 1992), bererti model kajian ini mempunyai kesan yang besar (Cohen, 1992).

Seterusnya, keputusan pengujian hipotesis menghasilkan tiga dapatan penting: Pertama, perkaitan antara KSMTB dan KKKLB adalah signifikan $(\beta=0.643 ; \mathrm{t}=12.059)$, oleh itu $\mathrm{H}_{1}$ disokong. Kedua, perkaitan antara PTGHB dengan KKKLB adalah signifikan $(\beta=0.711$; $\mathrm{t}=16.546$ ), oleh itu $\mathrm{H}_{2}$ disokong. Ketiga, perkaitan antara BBNTB dan KKKLB adalah signifikan $(\beta=0.668 ; \mathrm{t}=13.117)$, oleh itu $\mathrm{H}_{3}$ disokong. Dapatan pengujian hipotesis mengesahkan bahawa KSMTB, PTGHB dan BBNTB berupaya meningkatkan KKKLB.

Jadual 4. Dapatan pengujian $\mathrm{H}_{1}, \mathrm{H}_{2}$ dan $\mathrm{H}_{3}$

\begin{tabular}{cccccc}
\hline Hipotesis & Hubungan & Nilai $\boldsymbol{\beta}$ & Nilai $\boldsymbol{t}$ & $\mathbf{R}^{\mathbf{2}}$ & Keputusan \\
\hline $\mathrm{H}_{1}$ & $\mathrm{KSMTB} \rightarrow \mathrm{KKKLB}$ & 0.643 & 12.059 & 0.413 & Disokong \\
$\mathrm{H}_{2}$ & $\mathrm{PTGHB} \rightarrow \mathrm{KKKLB}$ & 0.711 & 16.546 & 0.506 & Disokong \\
$\mathrm{H}_{3}$ & $\mathrm{BBNTB} \rightarrow \mathrm{KKKLB}$ & 0.668 & 13.117 & 0.447 & Disokong \\
\hline
\end{tabular}

Nota: Signifikan $\mathrm{t}>1.65$ (one-tail test)

Seterusnya, ujian kesesuaian model, saiz kesan dan ketepatan jangkaan telah dilaksanakan secara berasingan berdasarkan prosedur bootstrapping dan blindfolding. Dapatan ujian kesepadanan model menghasilkan nilai estimated root mean square residual (SRMR) yang kurang daripada 0.08 atau 10.0 (Hu \& Bentler, 1999), bererti model kajian ini adalah sesuai. Manakala, pengujian saiz kesan memberikan nilai $\mathrm{f}^{2}$ sebanyak 0.705 untuk KSMTB, 1.023 untuk PTGHB dan 0.807 untuk BBNTB. Nilai-nilai ini lebih besar daripada 0.35. Menurut Hair et al. (2017), ini bermakna kesan konstruk terhadap KKKLB adalah besar. Selanjutnya, pengujian ketepatan jangkaan menghasilkan nilai $\mathrm{Q}^{2}$ sebanyak 0.264 untuk KSMTB, 0.324 untuk PTGHB dan 0.287 untuk BBNTB. Kesemua nilai tersebut lebih besar daripada sifar dan berpandukan kepada Hair et al. (2017) bererti konstruk telah mencapai tahap ketepatan ramalan.

\section{Dapatan pengujian Hipotesis $\mathrm{H}_{4}, \mathrm{H}_{5}$ dan $\mathrm{H}_{6}$}

Jadual 5 memaparkan kadar perubahan dalam pemboleh ubah bersandar iaitu KSMTB dan SKGPB telah menyumbang sebanyak 0.55 kepada perubahan dalam KKKLB. Nilai sumbangan ini lebih besar daripada 0.26 (Cohen, 1992), bermakna model kajian mempunyai kesan yang besar. Manakala, PTGHB dan SKGPB telah menyumbang sebanyak 0.62 kepada perubahan dalam KKKLB. Nilai sumbangan ini adalah lebih besar daripada 0.26 (Cohen, 1992), bermakna model kajian mempunyai kesan yang besar. Seterusnya, BBNTB dan SKGPB telah menyumbang sebanyak 0.57 kepada perubahan dalam KKKLB. Nilai sumbangan ini adalah lebih besar daripada 0.26 (Cohen, 1992), bermakna model kajian ini mempunyai kesan yang besar (Cohen, 1992).

Seterusnya, keputusan pengujian hipotesis menunjukkan tiga penemuan penting: Pertama, interaksi antara KSMTB dan SKGPB dengan KKKLB adalah signifikan $(\beta=0.073$; 
$\mathrm{t}=2.084)$. Ini bererti $\mathrm{H}_{4}$ disokong. Kedua, interaksi antara PTGHB dan SKGPB dengan KKKLB adalah signifikan $(\beta=0.048 ; \mathrm{t}=1.747)$. Ini bererti $\mathrm{H}_{5}$ disokong. Ketiga, interaksi antara BBNTB dan SKGPB mempunyai perkaitan yang signifikan dengan KKKLB $(\beta=0.167$; $\mathrm{t}=3.484)$. Ini bererti $\mathrm{H}_{6}$ disokong. Dapatan pengujian hipotesis mengesahkan bahawa kesan KSMTB, PTGHB dan BBNTB terhadap KKKLB disederhanakan oleh SKGPB.

Jadual 5. Keputusan pengujian hipotesis $\mathrm{H}_{4}, \mathrm{H}_{5}$ dan $\mathrm{H}_{6}$

\begin{tabular}{clcccc}
\hline Hipotesis & \multicolumn{1}{c}{ Hubungan } & Nilai $\boldsymbol{\beta}$ & Nilai $\boldsymbol{t}$ & $\mathbf{R}^{2}$ & Keputusan \\
\hline $\mathrm{H}_{4}$ & $\mathrm{KSMTB} \rightarrow \mathrm{SKGPB} \rightarrow \mathrm{KKKLB}$ & 0.073 & 2.084 & 0.55 & Disokong \\
$\mathrm{H}_{5}$ & $\mathrm{PTGHB} \rightarrow \mathrm{SKGPB} \rightarrow \mathrm{KKKLB}$ & 0.048 & 1.747 & 0.55 & Disokong \\
$\mathrm{H}_{6}$ & $\mathrm{BBNTB} \rightarrow \mathrm{SKGPB} \rightarrow \mathrm{KKKLB}$ & 0.167 & 3.484 & 0.57 & Disokong \\
\hline
\end{tabular}

Nota: Signifikan $\mathrm{t}>1.65$ (one tail test)

Selanjutnya, ujian kesesuaian model, saiz kesan dan ketepatan jangkaan telah dilaksanakan secara berasingan berdasar prosedur bootstrapping dan blindfolding. Ujian kesepadanan model menghasilkan nilai estimated root mean square residual (SRMR) yang kurang daripada 0.08 atau 10.0. Dengan nilai ini, menurut Hu dan Bentler (1999), model kajian adalah sesuai. Manakala itu, pengujian saiz kesan memberikan nilai $\mathrm{f}^{2}$ bagi interaksi antara KSMTB dan SKGPB dengan KKKLB sebanyak 0.017. Menurut Hair et al. (2017), nilai yang berada di antara 0.02 dan 0.15 bermakna SKGPB mempunyai kesan penyederhanaan yang lemah. Nilai $\mathrm{f}^{2}$ bagi interaksi antara PTGHTB dan SKGPB dengan KKKLB sebanyak 0.167 adalah terletak di antara 0.15 dan 0.35 yang bermaksud bahawa SKGPB mempunyai kesan penyederhanaan yang sederhana. Manakala, nilai $\mathrm{f}^{2}$ bagi interaksi antara BBNTB dan SKGPB dengan KKKLB sebanyak 0.019 yang terletak di antara 0.02 dan 0.15 , bermaksud bahawa SKGPB mempunyai kesan penyederhanaan yang lemah. Sebaliknya, pengujian ketepatan jangkaan menghasilkan nilai $\mathrm{Q}^{2}$ sebanyak 0.354 untuk KSMTB, 0.369 untuk PTGHB dan 0.374 untuk BBNTB. Menurut Hair et al. (2017), dengan nilai yang melebihi daripada sifar, konstruk tersebut telah mencapai tahap ketepatan jangkaan.

\section{Perbincangan dan implikasi}

Kajian ini menghasilkan dua penemuan penting: Pertama, tekanan kerja dapat meningkatkan konflik-kerja keluarga. Dapatan ini menunjukkan bahawa ketidakupayaan pekerja untuk mengorganisasi dan mengawal tekanan yang berpunca daripada kesamaran tangggungjawab, pertelingkahan tanggungjawab dan beban tanggungjawab dapat meningkatkan campurtangan urusan kerja terhadap keharmonian keluarga. Dapatan kajian ini adalah selari dengan kajiankajian yang dilakukan oleh Nabavi dan Shahryari (2012), Ogbogu (2013), Azman et al. (2014) dan Nurul Habibatunn et al. (2018).

Kedua, kesan tekanan kerja terhadap konflik kerja-keluarga dapat disederhanakan oleh sokongan penyelia. Dapatan ini menerangkan bahawa tahap kesamaran tangggungjawab, pertelingkahan tanggungjawab dan beban tanggungjawab yang tidak berupaya meningkatkan campurtangan urusan kerja terhadap keharmonian keluarga apabila penyelia sanggup menghulurkan sokongan emosi dan instrumental dalam operasi kerja harian. Dapatan kajian ini juga telah menyokong dan menyebarluas kajian-kajian yang dilaksanakan oleh Fu dan Shaffer (2001), Tharmalingan (2014) dan Asad (2018).

Kajian ini mengetengahkan tiga implikasi utama yang terdiri daripada sumbangan kepada teori, pemantapan kaedah penyelidikan dan pengamal. Dapatan kajian ini selari 
dengan idea utama yang dikemukakan oleh Teori Pertukaran Pemimpin-Pengikut (Dansereau et al., 1965), iaitu kualiti perhubungan di antara pemimpin dan pengikut dalam hierarki pentadbiran organisasi. Kualiti perhubungan ini biasanya digambarkan oleh kesanggupan dan keazaman penyelia untuk menghulurkan sokongan emosi dan instrumental membantu meningkatkan keupayaan pekerja untuk mengendalikan darjah tekanan kerja yang tinggi. Keadaan ini meningkatkan keupayaan pekerja untuk mengendali dan mengawal gangguan kerja harian terhadap kesejahteraan keluarga. Idea utama teori menerima sokongan yang kuat daripada kajian empirikal oleh Nabavi dan Shahryari (2012), Ogbogu (2013), Azman et al. (2014), Yu Fei et al. (2012), Tharmalingan \& Bhatti (2014), Tavassoli \& Sune (2018) dan Asad (2018).

Merujuk kepada pemantapan kaedah penyelidikan, borang soal selidik kajian telah menepati tahap kesahan dan kebolehpercayaan yang ditetapkan. Selanjutnya, sumbangan kepada pengamal apabila dapatan kajian boleh dijadikan panduan oleh pihak pengurusan untuk mengurangkan kesan negatif tekanan kerja dalam organisasi. Pihak pengurusan perlu mempertimbangkan aspek berikut: Pertama, senarai tugas perlu direka bentuk secara bersama dengan melibatkan para pekerja bagi memenuhi dan mencapai matlamat organisasi. Kedua, latihan yang berkaitan tugas perlu dilaksanakan oleh pihak pengurusan. Peningkatan kesefahaman antara pegawai atasan dan pekerja penting bagi meningkatkan pengetahuan, kemahiran dan sikap positif dalam pelaksanaan tugas. Ketiga, mengamalkan nilai murni yang tinggi antara pekerja atasan dan bawahan. Keempat, melatih penyelia sebagai mentor, jurulatih dan kaunselor bagi membimbing pekerja menguasai pengetahuan dan kemahiran baharu serta mengamalkan nilai-nilai murni. Kelima, gaya kepimpinan berorientasi manusia yang meringankan masalah kerja, mengawal emosi dan menggalakkan pemikiran rasional dalam menyelesaikan permasalahan kerja boleh diamalkan. Keenam, kemahiran komunikasi yang tinggi untuk mengurus pekerja menyelesaikan tugasan-tugasan sukar dalam organisasi.

\section{Batasan kajian}

Terdapat beberapa batasan konseptual dan metodologi kajian. Pertama, kaedah keratan rentas hanya menghuraikan tanggapan responden secara umum terhadap corak perhubungan antara pemboleh ubah dalam sampel kajian. Kedua, kajian tidak menguji perhubungan antara elemen-elemen bagi pemboleh ubah tidak bersandar, pemboleh ubah penyederhanaan dan pemboleh ubah bersandar. Ketiga, kajian ini dilaksanakan dalam sebuah organisasi yang ditadbirkan oleh kerajaan Persekutuan Malaysia. Keempat, teknik pensampelan bertujuan tidak berupaya mengawal maklum balas bias daripada responden kajian. Kekangan kajian mengurangkan keupayaan mengeneralisasikan hasil kajian kepada organisasi berbeza jenis dan corak pemilikan.

\section{Cadangan kajian akan datang}

Beberapa cadangan pemantapan kajian akan datang diutarakan. Pertama, ciri-ciri demografi responden seperti jantina, umur, jawatan dan status perkahwinan perlu diterokai bagi menunjukkan persamaan dan perbezaan persepsi responden terhadap tekanan kerja. Kedua, kaedah perbandingan bagi menguji keberkesanan sokongan penyelia sebagai pemboleh ubah penyederhanaan dalam organisasi swasta dan awam perlu dilaksanakan. Ianya dapat menilai saiz kesan sokongan penyelia sebagai pemboleh ubah penyederhanaan dalam latar organisasi kajian yang berbeza. Ketiga, saiz sampel yang lebih besar diperlukan bagi mewakili ciri-ciri populasi kajian. Keempat, elemen tekanan kerja yang spesifik, seperti ketidakjelasan senarai 
tugas, percanggahan pengharapan antara penyelia dan pekerja, serta kerja lebih masa perlu diberi perhatian (Azman et al., 2014; Nurul Habibatunn et al., 2018). Kelima, dimensi sokongan penyelia yang khusus, seperti bantuan maklumat dan sosialisasi perlu diselidiki sebagai pemboleh ubah penyederhanaan khusus yang penting antara tekanan kerja dan konflik kerja-keluarga (Tharmalingam \& Bhatti, 2014; Tavassoli \& Sune, 2018). Terakhir, ciri-ciri konflik kerja-keluarga yang khusus, seperti pembahagian masa kerja dan keluarga, serta perancangan urusan kerja serta keluarga wajar diteliti kerana merupakan kesan penting daripada perhubungan antara tekanan kerja dan sokongan penyelia (Tavassoli \& Sune, 2018; Asad, 2018). Cadangan di atas wajar diambilkira untuk memantapkan kajian akan datang.

\section{Kesimpulan}

Skala pengukuran kajian ini telah mencapai piawaian kesahan dan kebolehpercayaan yang ditetapkan. Keputusan analisis SmartPLS telah mengesahkan bahawa tahap tekanan kerja tidak dapat meningkatkan konflik-kerja keluarga apabila penyelia menghulurkan sokongan yang berkesan kepada pekerja dalam organisasi. Dapatan ini menyokong kajian lepas yang diterbitkan di negara-negara Barat dan Asia. Kajian ini mengesyorkan bahawa kesediaan penyelia menghulur sokongan yang memadai dapat meningkatkan kebolehan pekerja mengenalpasti, mengawal dan mengendalikan tekanan fisiologi dan psikologi dalam pelaksanaan kerja. Ini mendorong pekerja untuk melonjak dan mengekalkan prestasi serta daya saing organisasi.

\section{Rujukan}

Adnan, A. Suad, S., \& Asad, U.R. (2016). The effect of role overload on employee anxiety and organization citizenship behavior. European Journal of Business and Management Vol. $8(1), 1-6$.

Asad, U.R. (2018). Impact of abusive supervision on work family conflict and life satisfaction: mediating role of job stress and moderating role of social support. (Disertasi Sarjana). Dimuat naik dari Fakulti Pengurusan dan Sains Sosial, Capital University of Science and Technology, Islamabad.

Azman, I., Norhafizah, A.H., Yu Fei, C., Yusof, I., \& Ainon Jauhariah, A.S. (2013). Job stress

as a predictor of employee health. Studies in Business and Economics, 8, 20-34.

Azman, I., Wan Hafzainee, W.M., Fara Farihana, S., Rizal, A.B., Yusof, I., Maisarah, A., Mohd Hamran, M., \& Asmuni, A.G. (2014). Role stressor as an antecedent of employees family conflict: empirical evidence. Journal of Public Administration, Finance and Law, 6, 175-187.

Birhanu, M., Gebrekidan, B., Tesefa, G., \& Tareke, M. (2018). Workload determines workplace stress among health professionals working in Felege-Hiwot Referral Hospital, Bahir Dar, Northwest Ethiopia. Journal of Environmental and Public Health, $1-8$.

Clark, S.C. (2002). Employees' sense of community, sense of control, and work/family conflict in native American organizations. Journal of Vocational Behavior, 58, 348365.

Creswell, J.W. (2015). Research Design: Qualitative, Quantitative and Mixed Methods Approaches $\left(4^{\text {th }}\right.$ ed.). California: SAGE Publications.

Cohen, J. (1992). A power primer. Psychological Bulletin, 112, 155-159. 
Curran, T.M., \& Prottas, D.J. (2017). Role stressors, engagement and work behaviours: A study of higher education professional staff. Journal of Higher Education Policy and Management, 39(6), 642-657.

Dansereau, F., Graen, G., \& Haga, W.J. (1975). A vertical dyad linkage approach to leadership within formal organizations: A longitudinal investigation of the role making process. Organizational Behavior and Human Performance, 13(1), 46-78.

Eichhorn, B.R. (2014). Common Method Variance Techniques. Paper AA11-2014. Cleveland OH: Cleveland State University. Dimuat naik dari https://www.lexjansen.com/mwsug/ 2014/AA/MWSUG-2014-AA11.pdf

Erny Yusnida, C.Y., Haslinda, A., \& Zatul Himmah, A. (2017). Hubungan kepuasan kerja dengan kecerdasan emosi dalam kalangan warga polis diraja Malaysia. GeografiaMalaysia Journal of Society and Space, 13(1), 22-37

Fu, C.K., \& Shaffer, M.A. (2001). The tug of work and family: direct and indirect domainspecific determinants of work-family conflict. Personnel Review, 30, 502-522.

Gefen, D., \& Straub, D. (2005). A practical guide to factorial validity using PLS-Graph: Tutorial and annotated example. Communication of the Association for Information Systems, 16, 91-109.

Hair, J.F., Hult, G.T.M., Ringle, C.M., \& Sarstedt, M. (2017). A Primer on Partial Least Squares Structural Equation Modeling (PLS-SEM). (2 ${ }^{\text {nd }}$ Ed.). Los Angeles: SAGE Publications Inc.

Henseler, J., Ringle, C.M., \& Sinkovics, R.R. (2009). The use of partial least squares path modeling in international marketing. Advances in International Marketing, 20, 277 320.

Hirschi, A. (2018). The fourth industrial revolution: Issues and implications for career research and practice. The Career Development Quarterly, 66(3), 192-204.

Hu, L.T., \& Bentler, P.M. (1999). Cutoff Criteria for Fit Indexes in Covariance Structure Analysis: Conventional Criteria Versus New Alternatives. Structural Equation Modeling, 6(1), 1-55.

Jun Ju, Y.J., Park, E.-C., Ju, H.-J., Lee, S.A., Lee, J.E., Kim, W., \& Kim, T.H. (2017). The influence of family stress and conflict on depressive symptoms among working married women: A longitudinal study. Health Care for Women International, 39(3), 275-288.

Lee, M., Yun, J.J., Pyka, A., Won, D.K., Kodama, F., Schiuma, G., Park, H.S., Jeon, J., Park, K.B., Jung, K.H., Yan, M.R., Lee, S.Y., \& Zhoa, X. (2018). How to respond to the fourth industrial revolution or the second information technology revolution? Dynamic new combinations between technology, market and society through open innovation. Journal of Open Innovation: Technology, Market, and Complexity, 4(21), 2-14.

Nur Izzaty, M., Azman, I., Mohamad Shahril, A., Mohamad, R., \& Sholihien, A. (2015). Tekanan kerja dan perkaitannya dengan kesihatan pekerja: kajian empirikal sebuah kontinjen polis di Semenanjung Malaysia (Work stress and its relationship with workers health: An empirical study of a police contingent in Peninsular Malaysia). Geografia- Malaysia Journal of Society and Space, 11(10), 63-75.

Meguellati, A., Shahidra, A.K., Bahiyah, A., Mohd Roslan, M.N., \& Mohd Yakub Zulkifli, M.Y. (2017). Management and supervisory support as a moderator of work-family demands and women's well-being: a case study of Muslim female academicians in Malaysia. Humanomics, 33(3), 335-356.

Nabavi, A.H., \& Shahryari, M. (2012). Linkage between worksite support with work role expectation, role ambiguity and its effects on work-family conflict. Canadian Social Science, 8(4), 112-119. 
Netemeyer, R.G., Boles, J.S., \& Mcmurrian, R. (1996). Development and validation of workfamily conflict and family-work conflict scales. Journal of Applied Psychology, 81(4), 400-410.

Nurul Habibatunn. J., Zirwatul Aida, I., \& Mazida, M.D. (2018). Social support as a moderator of the relationship between work family conflict and family satisfaction. Management Science Letters, 8(9), 951-962.

Ogbogu, O. (2013). Work-family role conflict among academic women in Nigerian public universities. The 2013 WEI International Academic Conference Proceeding, 19-24.

Padsakoff, P.M., Mackenzie, S.B., Lee, J.Y., \& Podsakoff, N.P. (2003). Common method biases in behavioral research. A critical review of the literature and recommended remedies, Journal of Applied Psychology, 88(5), 879-903.

Rabenu, E., Tziner, A., \& Sharoni, G. (2017). The relationship between work-family conflict, stress, and work attitudes. International Journal of Manpower, 38(8), 1143-1156.

Ray, E.B., \& Miller, K.I. (1994). Social support, home/work stress and burnout: Who can help? Journal of Applied Psychology, 30(3), 357-373.

Rizzo, J.R., House, R.J., \& Lirtzman, S.I. (1970). Role conflict and ambiguity in complex organizations. Administrative Science Quarterly, 15(2), 150-163.

Ringle, C.M., Wende, S., \& Will, A. (2005). SmartPLS 2.0 (Beta). Hamburg: SmartPLS. Available at www.smartpls.de

Schwab, K. (2017). The Fourth Industrial Revolution. New York: Crown Business.

Sekaran, U., \& Bougie, R. 2016. Research methods for business: A skill building approach ( $7^{\text {th }}$ ed). United Kingdom: John Wiley \& Sons, Inc.

Straub, C., Vinkenburg, C.J., Kleef, M.V., \& Hofmans, J. (2018). Effective HR implementation: The impact of supervisor support for policy use on employee perceptions and attitudes. The International Journal of Human Resource Management, 29(22), 1-20.

Ślusarczyk, B. (2018). Industry 4.0-Are we ready? Polish Journal of Management Studies, $17(1), 232-248$.

Smith, T., Johns-Wolfe, E., Shields, G.S., Malat, J., Jacquez, F., \& Slavich, G.M. (2020). Associations between lifetime stress exposure and prenatal health behaviors. Stress and Health. 1-35

Sunanda, K. (2018). Influence of occupational role stressors on employees stress in it sector. OSR Journal of Humanities and Social Science, 23(5), 71-82.

Tavassoli, T., \& Sune, A. (2018). A national study on the antecedents and outcomes of work life balance in Iran. PEOPLE: International Journal of Social Sciences, 3(3), 16161636.

Tharmalingam, S.D., \& Bhatti, M.A. (2014). Work-family conflict: an investigation on job involvement, role ambiguity and job demand: Moderated by social support. Journal of Human Resource Management, 2(3), 52-62.

Vickovic, S.G., \& Morrow, W.J. (2019). Examining the influence of work-family conflict on job stress, job satisfaction and organizational commitment among correctional officers. Criminal Justice Review, 1-21.

Wang, Y.C., Shelley, H.L., \& Lin, W.C. (2018). The relation of career adaptability to work family experience and personal growth initiative among Taiwanese working parents. Journal of Employment Counseling, 55(1), 27-40.

Yu-Fei, M.C., Ismail, A., Ahmad, R., \& Kuek, T.Y. (2012). Impacts of role stressor characteristics on the workforce-organizational social support as the moderator. SouthAsia Journal of Marketing and Management Research, 2(3), 1-20. 